University of Nebraska - Lincoln

DigitalCommons@University of Nebraska - Lincoln

HPRCC Personnel Publications

High Plains Regional Climate Center

2013

\title{
Estimating Greenhouse Gas Emissions from a Waste Lagoon
}

Arturo I. Quintanar

Universidad Nacional Autonoma de Mexico, arturo.quintanar@atmosfera.unam.mx

Rezaul Mamood

University of Nebraska - Lincoln, rmahmood2@unl.edu

Nanh Lovanh

USDA ARS Animal Waste Management Research Unit

Justin M. Rawley

University of South Carolina

Evi Becerra-Acosta

Western Kentucky University

See next page for additional authors

Follow this and additional works at: https://digitalcommons.unl.edu/hprccpubs

Part of the Atmospheric Sciences Commons, Climate Commons, Environmental Indicators and Impact Assessment Commons, Environmental Monitoring Commons, Fresh Water Studies Commons, Hydrology Commons, Meteorology Commons, Natural Resources Management and Policy Commons, Sustainability Commons, and the Water Resource Management Commons

Quintanar, Arturo I.; Mamood, Rezaul; Lovanh, Nanh; Rawley, Justin M.; Becerra-Acosta, Evi; and Loughrin, John H., "Estimating Greenhouse Gas Emissions from a Waste Lagoon" (2013). HPRCC Personnel Publications. 1.

https://digitalcommons.unl.edu/hprccpubs/1

This Article is brought to you for free and open access by the High Plains Regional Climate Center at DigitalCommons@University of Nebraska - Lincoln. It has been accepted for inclusion in HPRCC Personnel Publications by an authorized administrator of DigitalCommons@University of Nebraska - Lincoln. 


\section{Authors}

Arturo I. Quintanar, Rezaul Mamood, Nanh Lovanh, Justin M. Rawley, Evi Becerra-Acosta, and John H. Loughrin 


\title{
ESTIMATING GREENHOUSE GAS EMISSIONS FROM A WASTE LAGOON
}

\author{
A.I. Quintanar, R. Mahmood, N. Lovanh, J. M. Rawley, \\ E. Becerra-Acosta, J. H. Loughrin
}

\begin{abstract}
A cost-effective approach was used to investigate the relationship between emission of the greenhouse gases (GHG), namely, $\mathrm{CO}_{2}, \mathrm{CH}_{4}$, and $\mathrm{N}_{2} \mathrm{O}$ and energy fluxes from a swine waste lagoon. Energy fluxes were calculated using the Penman method. The energy fluxes showed a diurnal pattern as expected of such fluxes. We found that air temperature and latent energy, lagoon surface temperature and solar radiation, as well as air temperature and wind speed can be used to predict for $\mathrm{CO}_{2}, \mathrm{CH}_{4}$, and $\mathrm{N}_{2} \mathrm{O}$ emissions, respectively. Comparison of observed and predicted emissions provided $r^{2}$ values of 0.49, 0.61, and 0.69 for $\mathrm{CH}_{4}, \mathrm{~N}_{2} \mathrm{O}$, and $\mathrm{CO}_{2}$, respectively. This research shows that long-term studies of $\mathrm{GHG}$ emissions and meteorological conditions are necessary to better understand the factors controlling the emissions of GHG in order to devise best management practices (BMP) for their control.
\end{abstract}

Keywords. Greenhouse gas ( $\mathrm{GHG}$ ), $\mathrm{CO}_{2}, \mathrm{CH}_{4}, \mathrm{~N}_{2} \mathrm{O}$, Energy flux, Livestock waste lagoon.

$\mathrm{H}$ uman activities including agriculture are an important source of greenhouse gas (GHG) emissions. It is noted that, globally, animal agriculture is the source of $9 \%$ of carbon dioxide $\left(\mathrm{CO}_{2}\right), 37 \%$ of methane $\left(\mathrm{CH}_{4}\right)$, and $65 \%$ of nitrous oxide $\left(\mathrm{N}_{2} \mathrm{O}\right)$ emissions (Steinfeld et al., 2006). In particular, animal waste lagoons are an important source of these GHGs (e.g., Ham, 1999; DeSutter and Ham, 2005). Emissions of these gases from waste lagoons depend on lagoon water temperature and, in some cases, wind speed and management practices (Mangino et al., 2002; Sharpe et al., 2002; Harper et al., 2004; DeSutter and Ham, 2005). In other words, different physical and chemical processes at the boundary between the lagoon and the atmosphere can either curb or augment the emissions of these gases as well as the energy and mass fluxes (Loughrin et al., 2006;

Submitted for review in November 2012 as manuscript number SW 10013; approved for publication by the Soil \& Water Division of ASABE in May 2013.

Mention of company or trade names is for description only and does not imply endorsement by the USDA. The USDA is an equal opportunity provider and employer.

The authors are Arturo I. Quintanar, Post-Doctoral Scholar, (currently Centro de Ciencias de la Atmosfera, Universidad Nacional Autónoma de México, Circuito Exterior, Ciudad Universitaria, México); Rezaul Mahmood, Professor, Department of Geography and Geology, Western Kentucky University, Bowling Green, Kentucky; Nanh Lovanh, ASABE Member, Environmental Engineer, Animal Waste Management Research Unit, USDA ARS, Bowling Green, Kentucky; Justin M. Rawley, Student, (NSF-REU participant at Western Kentucky University), University of South Carolina, Columbia, South Carolina; Evi BecerraAcosta, Western Kentucky University, John H. Loughrin, ASABE Member, Research Chemist, Animal Waste Management Research Unit, USDA ARS, Bowling Green, Kentucky. Corresponding author: Rezaul Mahmood, Department of Geography and Geology, 1906 College Heights Blvd., Western Kentucky University, Bowling Green, KY, 42101; phone: 270-745-5079; e-mail: rezaul.mahmood@wku.edu.
Lovanh et al., 2009). However, these processes are not well understood and it is critical that we improve understanding of meteorological influences on GHG emissions from waste lagoons and develop methods that would help us predict GHG emissions based on meteorological conditions.

Many previous studies have examined the energy and mass fluxes from bodies of water and waste lagoons (Condie and Webster, 1997; Assouline et al., 2008; Jacobs et al., 2008; Tanny et al., 2008; Quintanar et al., 2009; Elsawwaf et al., 2010; Loughrin et al., 2012). One familiar method is the Bowen Ratio Energy Balance (BREB) which incorporates the ratio of the sensible energy flux to the latent heat flux. These fluxes are characterized in terms of the measured vertical gradients of temperature and moisture (Bowen, 1926; Penman, 1948; Priestley and Taylor, 1972; Philip, 1987; Andreas and Cash, 1996; Spence et al., 2003; Irmak and Irmak, 2008; Quintanar et al., 2009). Ohmura (1982) highlighted several problems with the BREB method while others have analyzed the accuracy of BREB (Perez et al., 1999). Another, and perhaps more common method, is the Penman formulation (Penman, 1948; Brutsaert, 2005) of evaporation which combined with energy constraints can produce reliable estimates of sensible and latent heat fluxes. The Penman method (1948) is one of the most reliable, stable, and costeffective approach to estimate latent energy flux or evaporation from variety of surfaces. This has led to widespread adoption of original or slightly modified version of this method for various applications that require evaporation estimation (e. g., Krishnan and Kushwaha, 1971; Shnitnikov, 1974; Doorenbos and Pruitt, 1977; Cohen et al., 2002; Mahmood and Hubbard, 2002, 2003, 2005; Wohlfahrt et al., 2009; Quintanar et al., 2009; Loughrin et al., 2011, 2012). 
Characterizing the meteorological relationships to GHG emissions could be achieved by simultaneous monitoring of meteorological fluxes using Eddy-covariance (EC) method and by measurement of $\mathrm{GHG}\left(\mathrm{CO}_{2}, \mathrm{CH}_{4}\right.$, and $\left.\mathrm{N}_{2} \mathrm{O}\right)$ emissions. However, this system is quite expensive. Here we propose a robust and reliable lower-cost flux estimation system that could be used in-place of expensive EC method and, subsequently, develop GHG emission estimation methods. The latter was developed based on the relationship between observed GHG emissions and estimated fluxes from a waste lagoon.

This research is part of a larger effort where the authors are trying to identify the relationships between meteorological variables and GHG emissions from waste lagoons and develop cost-effective approaches to estimate these emissions. Quintanar et al. (2009) and Loughrin et al. (2011) previously successfully estimated energy fluxes from a waste lagoon using Penman (1948) method. The present study follows these works using methodologies from Quintanar et al. (2009) and Loughrin et al. (2011) for energy flux estimates. The energy flux estimation method of the latter is an update of the former. Subsequently, this research used the Loughrin et al. (2012) statistical approach to establish the relationship between fluxes and GHG emissions (i.e., GHG emission method). We suggest that the results from the current study will help better understand the relationship between meteorological fluxes and GHG emissions. Furthermore, it is anticipated that these findings will help operators to devise better management practices (BMP) so they can reduce GHG emissions from the waste lagoon and help mitigate global warming.

\section{MATERIALS AND MethodS EXPERIMENTAL SET UP}

The research site was a farrowing farm containing approximately 2,000 sows located in Logan County $\left(36^{\circ}\right.$ $42^{\prime} \mathrm{N}, 86^{\circ} 42^{\prime} \mathrm{W}$ ) in South Central Kentucky. At the farm, an anaerobic lagoon of $65 \times 65 \mathrm{~m}$ and $3 \mathrm{~m}$ in depth is used to treat wastewater from four houses located around $100 \mathrm{~m}$ away from the lagoon bank. Most of the surrounding land is used for producing crops.

Data were collected for the entire month of February, 2009. Only days with mostly clear sky conditions and no precipitation were chosen to be studied in order to improve net radiation estimates. The days studied were 5, 7, 8, 9, and 12 of February. Gas measurements and meteorological data were collected every $5 \mathrm{~min}$. In addition, a surface weather station was installed about $20 \mathrm{~m}$ away from the southwest corner of the lagoon to measure meteorological conditions.

Lagoon measurements were made on two floating stations that carried instrumentation. Each station recorded temperature, relative humidity, and wind speed at 0.5 and $1.5 \mathrm{~m}$ above the lagoon surface. For this study we used data from the $0.5 \mathrm{~m}$ level. Greenhouse gas emissions were also measured $0.5 \mathrm{~m}$ above the lagoon's surface. Measurements from the two floating stations were used to account for systematic errors and data quality control. To maximize the amount of fetch to around $60 \mathrm{~m}$, the stations were deployed around the center of the lagoon. Since the lowest level of thermometer and hygrometer placement was $0.5 \mathrm{~m}$ above the water surface, for our $65 \times 65 \mathrm{~m}$ lagoon, the shortest fetch-to-height ratio was $60: 1$ and the longest 90:1. For a variety of conditions of fetch-to-height ratios, Stannard (1997; fig. 2d) has shown that a ratio of 60:1 can give a Bowen ratio that is about $80 \%$ equilibrated. In this research effort we used the Stannard (1997) criteria. These criteria were also successfully applied by the authors for similar studies (Loughrin et al., 2011, 2012; Quintanar et al., 2009).

\section{METEOROLOGICAL INSTRUMENTATION}

In this study a series of meteorological variables were measured so that meteorological fluxes could be estimated. Meteorological variables included temperature (lagoon surface and subsurface at depths of $0.3,0.6,0.9 \mathrm{~m}$ and lagoon bottom), relative humidity, barometric pressure, wind speed and direction, and solar radiation. The two rafts carried weather stations (APRS World, Winona, Minn.) with relative humidity-temperature sensors and anemometers (fig. 1). The resolution of the anemometers was around $0.1 \mathrm{~m} \mathrm{~s}^{-1}$ with an accuracy of $0.4 \mathrm{~m} \mathrm{~s}^{-1}$ and a minimum measurable wind speed of $0.5 \mathrm{~m} \mathrm{~s}^{-1}$. With a response time of $50 \mathrm{~s}$, the temperature sensors had a measurement range of $-26^{\circ} \mathrm{C}$ to $70^{\circ} \mathrm{C}$ and an accuracy of $0.5^{\circ} \mathrm{C}$. The non-condensing humidity sensors had an accuracy of $\pm 2 \%$ and a measurement range of 3 to $100 \%$ relative humidity. The humidity sensors had a linearity of $\pm 0.5 \%$, a hysteresis of $1 \%$ and a response time of $25 \mathrm{~s}$. A waterproof cable connected the weather stations on the rafts to a solar-powered data collection system on the bank of the lagoon that recorded data every $5 \mathrm{~min}$. To ensure that the data was collected at the same location on the lagoon's surface for each day, both rafts were secured approximately at the center of the lagoon with anchors and cables attached to the lagoon bank at two positions. HOBO U22 Pro v2 temperature sensors (Onset Computer Inc., Bourne, Mass.) recorded water temperatures every $5 \mathrm{~min}$ at the lagoon

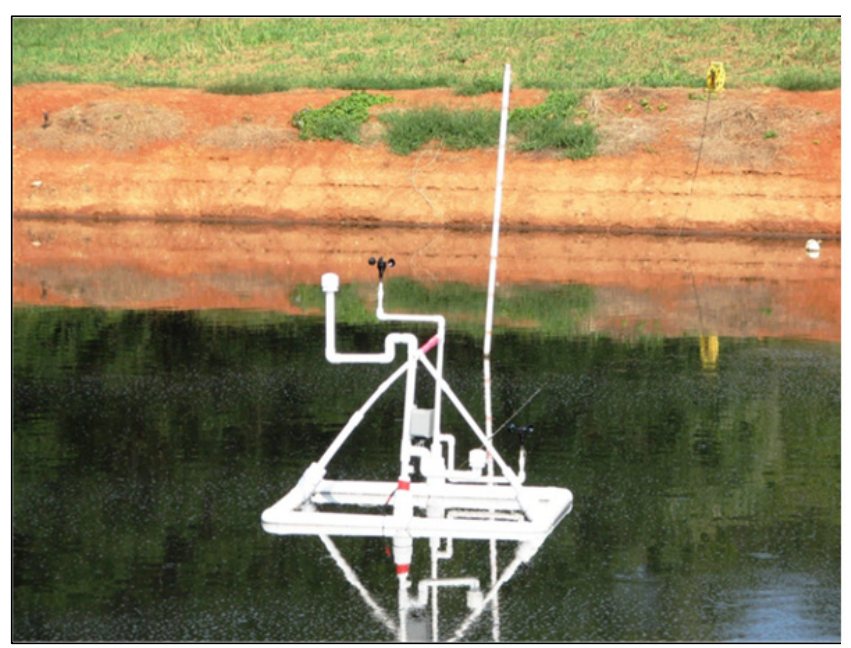

Figure 1. Meteorological instrumentation in the lagoon. 
surface as well as at depths of $0.3,0.6$, and $0.9 \mathrm{~m}$ below the surface of the lagoon. These sensors had an accuracy of $0.2^{\circ} \mathrm{C}$, a measurement range of $-26^{\circ} \mathrm{C}$ to $70^{\circ} \mathrm{C}$, and a resolution of $0.02^{\circ} \mathrm{C}$ at $25^{\circ} \mathrm{C}$.

Land-based meteorological measurements were collected approximately $20 \mathrm{~m}$ from the lagoon. These measures were made using a $\mathrm{HOBO}$ weather station (H21001, Onset Computer Inc., Bourne, Mass.) equipped with a cup anemometer at $3 \mathrm{~m}$ above the ground, a barometer, temperature and relative humidity sensors and a silicon pyranometer (spectral range of 300 to $1100 \mathrm{~nm}$ ) positioned at $2 \mathrm{~m}$ above the ground. As in Quintanar et al. (2009), to test for the soundness of the data, the land station data were compared with the data from the stations on the lagoon.

All these meteorological data were used in-conjunction with well-known methods (e.g., Penman, 1948; Brutsaert, 2005) to estimate latent, sensible and lagoon storage heat fluxes. For this study net radiation was estimated using the approach developed by Brutsaert (2005) and presented in Quintanar et al. (2009). It was successfully applied in several previous studies by the authors (Loughrin et al., 2011, 2012). Others researchers have also used the methods to estimate net radiation in the absence of direct observations (e.g., De Jong, 1980; Linacre, 1968; Novak et al., 2000; Wang and Liang, 2009).

\section{Greenhouse Gas Measurements}

GHG emissions were monitored using a Photoacoustic Gas Analyzer (Innova model 1412, Innova Air Tech Instruments A/S, Denmark). The Innova 1412 multi-gas analyzer used a 1-s sampling integration time and fixed flushing time: $2 \mathrm{~s}$ for the chamber and $3 \mathrm{~s}$ for the tubing. The required time to complete one sampling cycle was approximately $70 \mathrm{~s}$. The response time of the analyzer to step changes in gas emissions was tested. Greenhouse gas emissions were monitored at $0.5 \mathrm{~m}$ above the lagoon surface (to match meteorological measurements). The gas analyzer was housed in a trailer near the lagoon.

\section{ENERgy FluX Estimation Methods}

In the energy budget of the lagoon, it was assumed that local advection of moisture and heat terms (Philip, 1987; Arya, 2001; Brutsaert, 2005) were negligible. Thus, the energy balance equation at the lagoon surface can be written as:

$$
L S=R_{N}-\left(H+L_{e} E\right)
$$

where $L S$ is the lagoon heat storage or net heat flux into the lagoon (Smith, 1985; Oke, 1987; Garratt et al., 1993; Rodriguez-Rodriguez and Moreno-Ostos, 2006), $R_{N}$ is the net radiation at the surface, $H$ corresponds to the sensible heat flux, $L_{e}$ represents the latent heat of vaporization, and $E$ is the evaporation rate. Consistently with positive $L S$, the sign convention is that $H$ and $L_{e} E$ fluxes are positive upwards (away from the lagoon surface). Details of $L S$ calculation can be found in the appendix (eqs. A1-2). Because direct measurements of net radiation were not made, the calculations in Brutsaert (2005) were employed. Consequently, the net radiation term can be written as:

$$
R_{N}=R_{S}\left(1-\alpha_{S}\right)+\varepsilon_{S} R_{L D}-R_{L U}
$$

where $R_{S}$ is the short-wave radiation, $\alpha_{S}$ corresponds to the albedo of the water surface, $R_{L D}$ is the incoming long-wave radiation downward to the surface, $\varepsilon_{S}$ represents the emissivity of the lagoon surface, and $R_{L U}$ is the outgoing long-wave radiation away from the surface. Details of the calculation of various components of $R_{N}$ could be found in the appendix (eqs. A3-5).

Computation of evaporation rates at above the lagoon surface uses Penman (1948) equation, namely:

$$
E=\frac{\Delta}{\Delta+\gamma}\left(R_{N}-G\right)+\frac{\gamma}{\Delta+\gamma} E_{A}
$$

where $\Delta=\left(d e^{*} / d p\right)$ is the slope of the saturation vapor pressure $\left(e^{*}\right)$ and it is a function of the lagoon surface $T_{s}, \gamma$ $=$ is the psychrometric 'constant', $p$ is atmospheric pressure $(\mathrm{Pa})$ and $E_{A}(\mathrm{~mm} / \mathrm{h})$ is represented as:

$$
E_{A}=f(\bar{u})\left(e_{a}^{*}-\bar{e}_{a}\right)
$$

where $f(\bar{u})=0.01(1+0.54 \bar{u})$ and represents a turbulent mass exchange coefficient originally proposed by Penman (1948) for open water. The terms $e_{a}^{*}$ and $\bar{e}_{a}$ are, respectively, the saturation vapor pressure and the atmospheric water vapor pressure measured at $0.5 \mathrm{~m}$ level above the lagoon surface. Calculation of $R_{N}, L S$, and $L_{e} E$ allowed us to derive $H$ as a residual term from equation 1 .

\section{RESULTS \\ Regional Meteorological Conditions}

The North American Regional Reanalysis (NARR) (Mesinger et al., 2006) data were used to characterize the general meteorological synoptic conditions for 5, 7, 8, 9, and 12 February 2009 for the Logan County, Kentucky region. Weatherwise, Kentucky was under the influence of a large high pressure system on 5 February 2009. The average pressure was $1033 \mathrm{mb}$. For the most part, the entire day was clear with no precipitation and light winds $\left(2 \mathrm{~m} \mathrm{~s}^{-1}\right.$ from the south). On 7 February 2009, Kentucky was under a high pressure system with a pressure around $1025 \mathrm{mb}$ and no precipitation. Skies were also clear early in the morning but became mostly cloudy throughout the day. Winds were from the southwest at around $5 \mathrm{~m} \mathrm{~s}^{-1}$. A cold front started to push through Kentucky and transitioning into a stationary front on 8 February 2009. The pressure was around $1026 \mathrm{mb}$. The winds were generally from the southwest at $2 \mathrm{~m} \mathrm{~s}^{-1}$. The skies were mostly cloudy in the early morning but the clouds broke up throughout the day becoming clear by the night. On 9 February, 2009, a stationary front was transitioned into a warm front and was located south of Kentucky. The pressure was $1023 \mathrm{mb}$ with mostly clear skies for most of the day. Winds were around $4.5 \mathrm{~m} \mathrm{~s}^{-1}$ out of the south. Two highs were located over Nebraska and Arkansas/Mississippi with some ridging over Kentucky on 12 February 2009. The pressure was around $1020 \mathrm{mb}$ with cloudy skies early in the morning and became clear with no 
precipitation. Winds were from the west at $2.5 \mathrm{~m} \mathrm{~s}^{-1}$. In summary, except for brief instances, all days analyzed in this study can be approximated as clear days for radiation computations.

\section{METEOROLOGICAL CONDITION AT THE LAGOON}

The analysis for clear day conditions was completed using time series of meteorological variables for February of 2009 (hereafter referred to as 28-day ensemble) for the lagoon. They were compared to the $5,7,8,9$ and 12 February clear-day ensemble (hereafter referred to as 5-day ensemble). Moreover, 369 data points correspond to 5-min data during these five days when measurements of GHGs were available. As a result, these days were separated from the rest of the time series. GHG data were collected for every $70 \mathrm{~s}$ and the average values for each 5-min interval were then used to synchronize to the available meteorological data. Subsequently, these data were used to construct the multivariate model by using corresponding meteorological and flux data.

Figure 2a shows the hourly temperature at $0.5 \mathrm{~m}$ above the lagoon surface for the 28-day ensemble. Median temperatures varied between $5^{\circ} \mathrm{C}$ and $6^{\circ} \mathrm{C}$ early in the morning ( 2 a.m. local time) and later in the evening ( 8 p.m. local time). The data also show a diurnal maximum of $13^{\circ} \mathrm{C}$. Upper quartiles were about $5^{\circ} \mathrm{C}$ to $8^{\circ} \mathrm{C}$ above median values while lower quartiles were about $5^{\circ} \mathrm{C}$ to $7^{\circ} \mathrm{C}$ smaller and follow a diurnal cycle as well. The data show a wide range of variations as temperatures fluctuated between - $10^{\circ} \mathrm{C}$ to $20^{\circ} \mathrm{C}$. Figure $2 \mathrm{~b}$ shows the corresponding hourly ensemble of temperatures based on the 5-day ensemble. A diurnal signal was more pronounced as these were clear days and median values of temperature are significantly higher by at least $7^{\circ} \mathrm{C}$ than those of the 28 -day ensemble. Further inspection of both figures $2 \mathrm{a}$ and $2 \mathrm{~b}$ shows that the 5 -day ensemble exhibits a slightly smaller spread than the 28 -day ensemble. Like its 28-day ensemble counterpart, the 5-day ensemble also exhibits a wide range of hour-by-hour variation. Time series for air temperatures from the HOBO station (not shown) exhibited a very similar pattern.

Figures $2 \mathrm{c}-\mathrm{d}$ shows the hourly data for wind speed at $0.5 \mathrm{~m}$ for 28-day ensemble and for the 5-day ensemble, respectively. The wind speed medians for the 28-day ensemble show small values of $0.7 \mathrm{~m} \mathrm{~s}^{-1}$ in the early morning (2 a.m. local time) and in the evening (8 p.m. local time). While it increased up to $3.2 \mathrm{~m} \mathrm{~s}^{-1}$ between 11 a.m. and 12 noon. Wind speeds reached up to $9.5 \mathrm{~m} \mathrm{~s}^{-1}$ for the 28-day ensemble. Median wind speed for the 5-day ensemble (fig. 2d) ranged from about $2.6 \mathrm{~m} \mathrm{~s}^{-1}$ in the early morning to about $3.4 \mathrm{~m} \mathrm{~s}^{-1}$ during mid-afternoon. The position of the medians also indicate that wind speed data were skewed towards higher values early in the morning and towards lower values during the afternoon hours.

\section{RADIATION AND ENERGY FLUXES}

Figure 3a shows the 28-day ensemble for solar radiation. The median peaked at 11 a.m. (local time) with a value of $542 \mathrm{~W} \mathrm{~m}^{-2}$. The rather large spread in the data, particularly
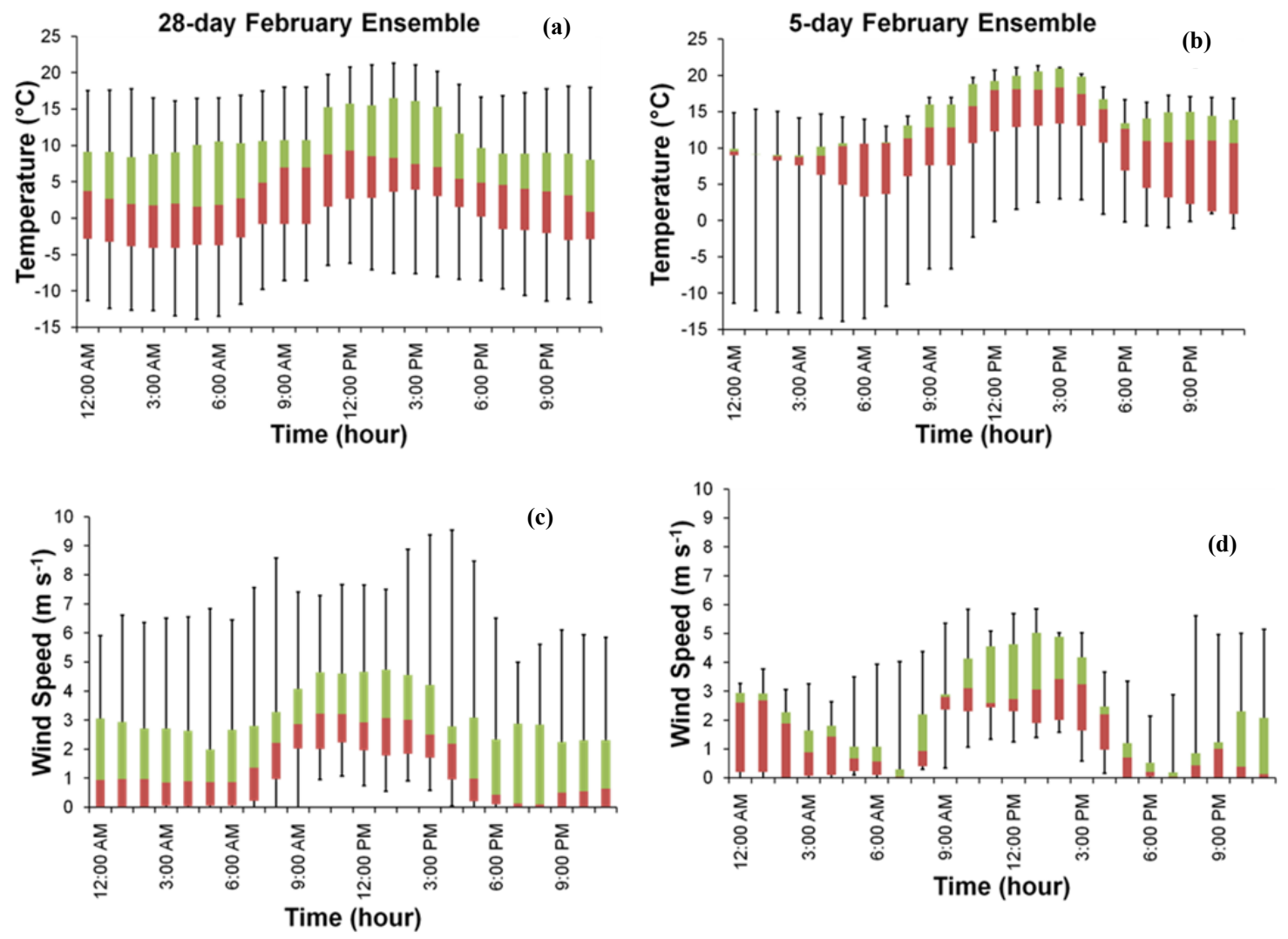

Figure 2. Time series of temperature at $0.5 \mathrm{~m}$ for: (a) 28-day hourly February ensemble and (b) 5-day hourly February ensemble. Time series of wind speed at $0.5 \mathrm{~m}$ for: (c) 28-day hourly February ensemble and (d) 5-day hourly February ensemble. 

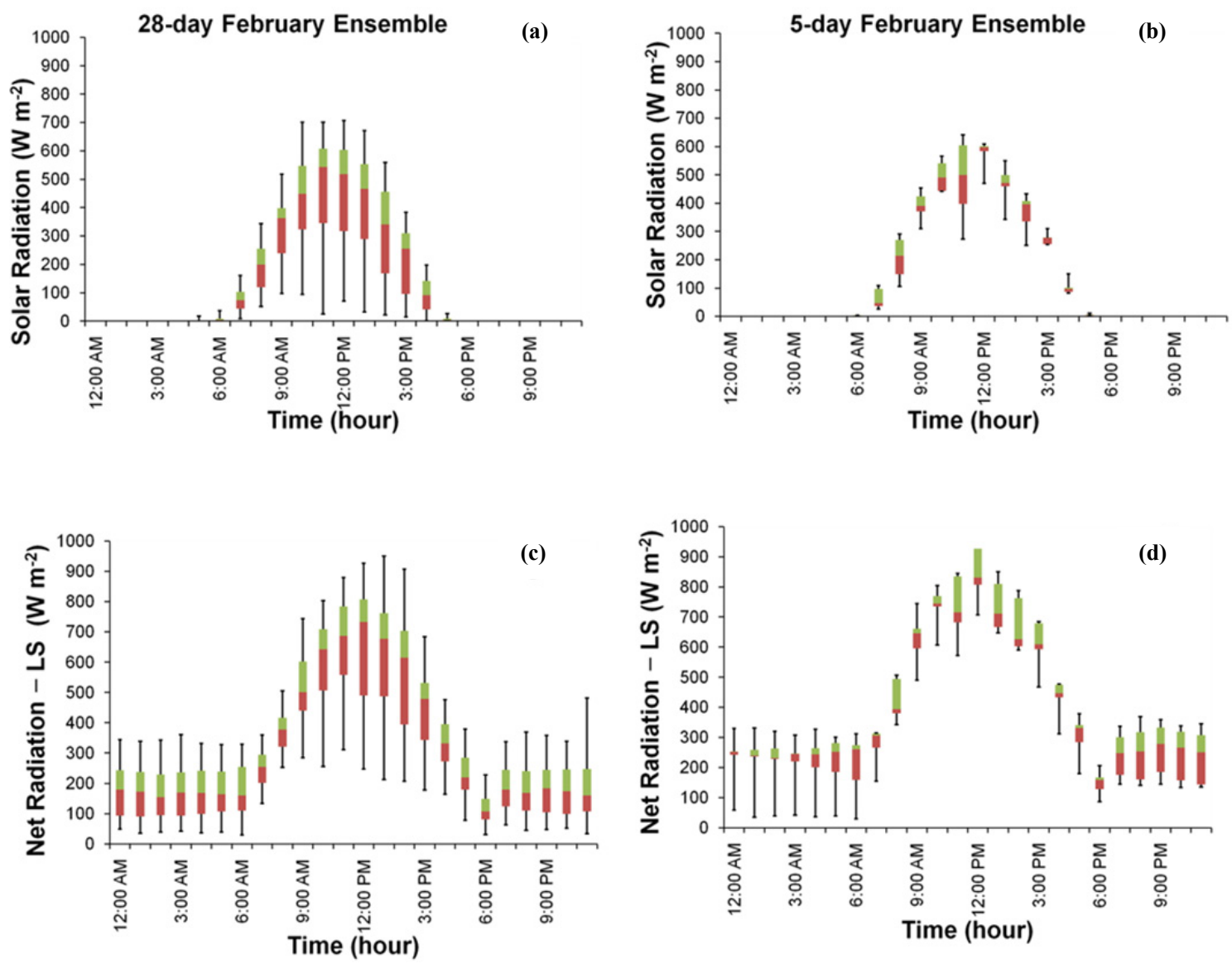

Figure 3. Time series of solar radiation for: (a) 28-day hourly February ensemble and (b) 5-day hourly February ensemble. Time series of available energy $\left(R_{N}-L S\right)$ for: (c) 28-day hourly February ensemble and (d) 5-day hourly February ensemble.

around noon, was brought about by the presence of clouds. The 5-day ensemble shows (fig. 3b) the largest value of the median to be $597 \mathrm{~W} \mathrm{~m}^{-2}$ around noon (local time). Data spread was smaller than the 28-day ensemble. In this ensemble, 5 February (not shown) did not show any noticeable short-term fluctuations in radiation due to absence of clouds. This is consistent with the synoptic analysis presented above. The rest of the days showed fluctuations due to the presence of clouds. This is also consistent with the synoptic conditions.

Figure 3c shows the available energy flux $\left(R_{N}-L S\right)$ for the 28-day ensemble at the surface as given by the difference between net solar radiation and lagoon heating computed as previously discussed (cf. eq. 1 and A1-2). Median values reached up to $542 \mathrm{~W} \mathrm{~m}^{-2}$ at 11 a.m. with fluctuations of about $600 \mathrm{~W} \mathrm{~m}^{-2}$ around this median values. Figure $3 \mathrm{~d}$ shows the 5-day ensemble for $R_{N}-L S$ with an expected larger median value of $830 \mathrm{~W} \mathrm{~m}^{-2}$ at local noon. Larger values of $R_{N}-L S$ than those observed for solar radiation (fig. 3b) were due to higher atmospheric emissivities and rather small outgoing long-wave radiation contributing to an increase of available energy at the surface.

Figure 4a shows the 28-day ensemble of latent heat flux $\left(L_{e} E\right)$ with median values of about $433 \mathrm{~W} \mathrm{~m}^{-2}$ at $1 \mathrm{p} . \mathrm{m}$. (local time) and with lower values both early morning and late at night of about $100 \mathrm{~W} \mathrm{~m}^{-2}$. Figure $4 \mathrm{~b}$ shows the corresponding 5-day ensemble for $L_{e} E$. The median in this case peaks at about $550 \mathrm{~W} \mathrm{~m}^{-2}$ around 11 a.m. (local time). The range of values for the 28- and 5-day ensembles differs substantially from one another because of sample size. However, it is noted that in the 5-day ensemble case the data are significantly skewed towards lower values (the size of the lower whiskers is about 20 to $50 \mathrm{~W} \mathrm{~m}^{-2}$ ).

Figure $4 \mathrm{c}$ shows the 28-day ensemble of sensible heat flux $(H)$ with median values reaching about $278 \mathrm{~W} \mathrm{~m}^{-2}$ at local noon and with smaller values of about $100 \mathrm{~W} \mathrm{~m}^{-2}$ during early morning and late evening. Medians show a spread of about $300 \mathrm{~W} \mathrm{~m}^{-2}$ around noon. Figure $4 \mathrm{~d}$ shows $H$ for the 5-day ensemble with a median that reached up to $299 \mathrm{~W} \mathrm{~m}^{-2}$ around local noon. It is noted that values of $H$ were significantly smaller by a factor of 1.5 than those of $L_{e} E$ indicating that available energy at the lagoon surface was used mainly for evaporation to the atmosphere. These results are consistent with the lagoon being a source of heat and moisture to the drier February atmosphere.

\section{EMISSIONS OF $\mathrm{CH}_{4}, \mathrm{CO}_{2}$, AND $\mathrm{N}_{2} \mathrm{O}$}

Measurements for $\mathrm{CH}_{4}, \mathrm{CO}_{2}$, and $\mathrm{N}_{2} \mathrm{O}$ were available only in the time period from local noon to 9 p.m. during days 5, 7, 8, 9, 12 February. Figure 5a shows the time series of hourly 5-day ensembles gas emissions for $\mathrm{CH}_{4}$ for this period. It was found that median emission increased from $37.2 \mathrm{ppm}$ at 12 noon to about $89.7 \mathrm{ppm}$ at $6 \mathrm{p} . \mathrm{m}$. (local 

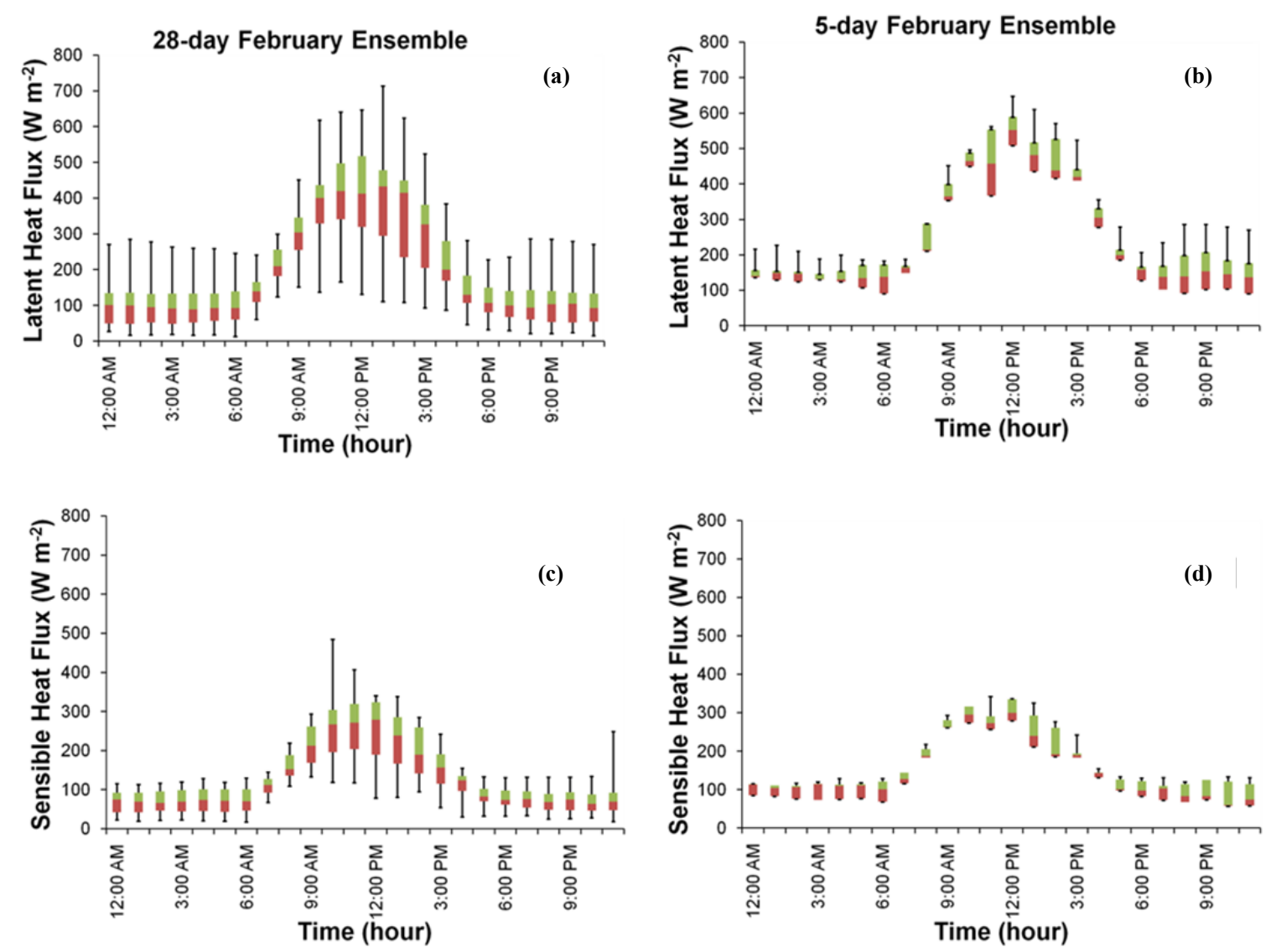

Figure 4. Time series of latent heat flux for: (a) 28-day hourly February ensemble and (b) 5-day hourly February ensemble. Time series of sensible heat flux for: (c) 28-day hourly February ensemble and (d) 5-day hourly February ensemble.

time) and remained nearly constant around $87.0 \mathrm{ppm}$ until 9 p.m. (local time). The spread of the data is noticeable from 12 noon to 5 p.m. (local times) with values ranging from 60 to $80 \mathrm{ppm}$. After 5 p.m. (local time) the spread of quartiles were reduced to less than $10 \mathrm{ppm}$. This was inpart due to the small sample size and in-part linked to turbulent mixing being suppressed later in the evening.

Figure $5 \mathrm{~b}$ shows emissions of $\mathrm{CO}_{2}$ for the same period. In this case, median emissions of $\mathrm{CO}_{2}$ did not show a clear tendency and remained clustered around $450 \mathrm{ppm}$. However, a marked spread at 5 p.m. (local time) was observed when the maximum reached up to $726 \mathrm{ppm}$. Figure 5c shows the corresponding 5-day ensemble time series for $\mathrm{N}_{2} \mathrm{O}$. Inspection of medians revealed a very similar pattern as displayed by $\mathrm{CH}_{4}$. Emission values of the median increased from $0.71 \mathrm{ppm}$ at 12 noon to $0.91 \mathrm{ppm}$ at 4 p.m. (local times) and subsequently remained constant at about $0.95 \mathrm{ppm}$.

\section{RELATIONSHIPS AMONG LAGOON METEOROLOGICAL VARIABLES AND GHG EMISSIONS}

From the above results and qualitative comparison of meteorological and emissions data, it is clear that possible correlations could be sought among lagoon atmospheric and surface variables and the measured GHG species. Here, the guiding principle was to choose the largest possible correlation, as determined by using multiple-linear regression analysis. The variables included were emissions of GHGs, lagoon measured and estimated physical variables, namely, air temperature from HOBO station $(T)$, air temperature at $0.5 \mathrm{~m}$ above the lagoon surface $\left(T_{0.5 \mathrm{~m}}\right)$, lagoon surface temperature $\left(T_{S R F}\right)$, net radiation $\left(R_{N}\right)$, lagoon heating $(L S)$, available energy at the surface $\left(R_{N^{-}} G\right)$, sensible heat flux $(H)$, latent heat flux $\left(L_{e} E\right)$, wind speed at $0.5 \mathrm{~m}\left(W S P_{0.5 \mathrm{~m}}\right)$ and solar radiation $\left(R_{S}\right)$. The methodology used here closely followed that of the Loughrin et al. (2011). Combinations among the above variables were performed to maximize correlations $\left(r^{2}\right)$ with a multivariable statistical model for emissions. Based on these analyses, the following models were selected $(n=369)$ :

$$
\begin{aligned}
& {\left[\mathrm{CH}_{4}\right]=32.2738+5.5945(\mathrm{~T})-0.1343(\mathrm{LeE})} \\
& {\left[\mathrm{N}_{2} \mathrm{O}\right]=1.1935-0.0303\left(T_{S R F}\right)-0.003(R s)} \\
& {\left[\mathrm{CO}_{2}\right]=775.0257-18.1715\left(\mathrm{~T}_{0.5 \mathrm{~m}}\right)} \\
& +5.9595\left(W P_{0.5 m}\right)
\end{aligned}
$$

Subsequently, the performance of these models was further assessed. Comparison of observed and predicted emission provided $r^{2}$ of $0.491(\mathrm{P}<0.001)$ for the $\mathrm{CH}_{4}$ model (eq. 5), $0.618(\mathrm{P}<0.001)$ for the $\mathrm{N}_{2} \mathrm{O}$ model (eq. 6), and 0.6934 for the $\mathrm{CO}_{2}$ model (eq. 7) (figs. 6a-c). The mean and standard errors of estimated $\mathrm{CH}_{4}, \mathrm{~N}_{2} \mathrm{O}$, and $\mathrm{CO}_{2}$ emissions were 73.11 and $1.58,0.883$ and 0.008 , and 480.62 and 3.33 ppm, respectively. It was also found that all three models 

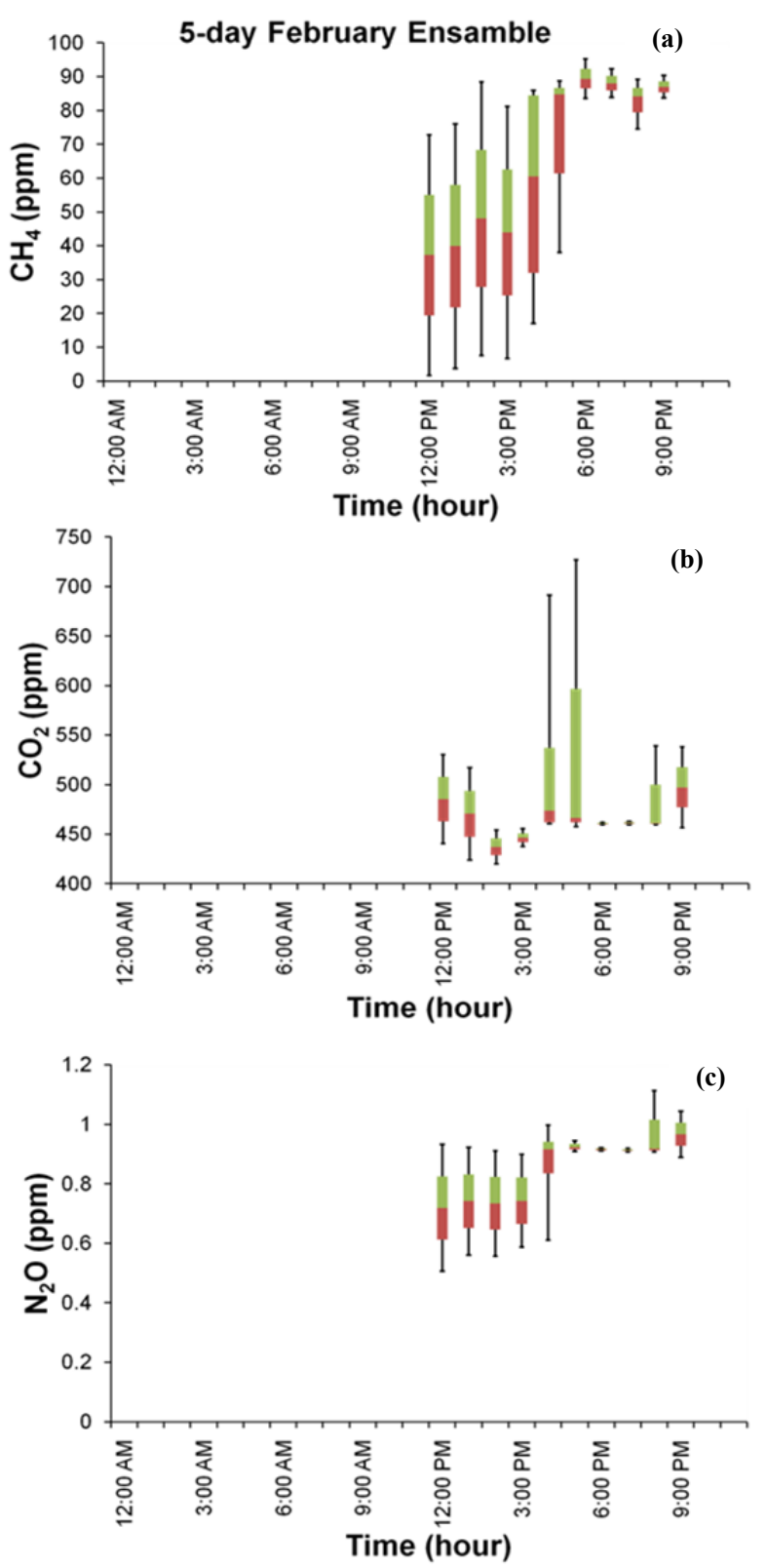

Figure 5. Time series of 5-day February ensemble for atmospheric gas emissions of: (a) $\mathrm{CH}_{4}$, (b) $\mathrm{CO}_{2}$ and (c) $\mathrm{N}_{2} \mathrm{O}$.

had a tendency to underestimate high GHG emissions and overestimate low emissions. Further inspection for $\mathrm{CH}_{4}$ revealed that most of the observations were of the higher emissions with values between 80 to $100 \mathrm{ppm}$, fewer observations for lower emissions and with very few points measured in between. Figure $6 \mathrm{~b}$ corresponds to the $\mathrm{N}_{2} \mathrm{O}$ model which has less bias than the $\mathrm{CH}_{4}$ model. Finally, figure $6 \mathrm{c}$ shows that the $\mathrm{CO}_{2}$ model with many observations of lower emissions at about $400 \mathrm{ppm}$ and the rest of observations distributed unevenly from 500 to 700 ppm. However, a larger GHG emissions dataset would provide a better assessment of the accuracy of the proposed models.
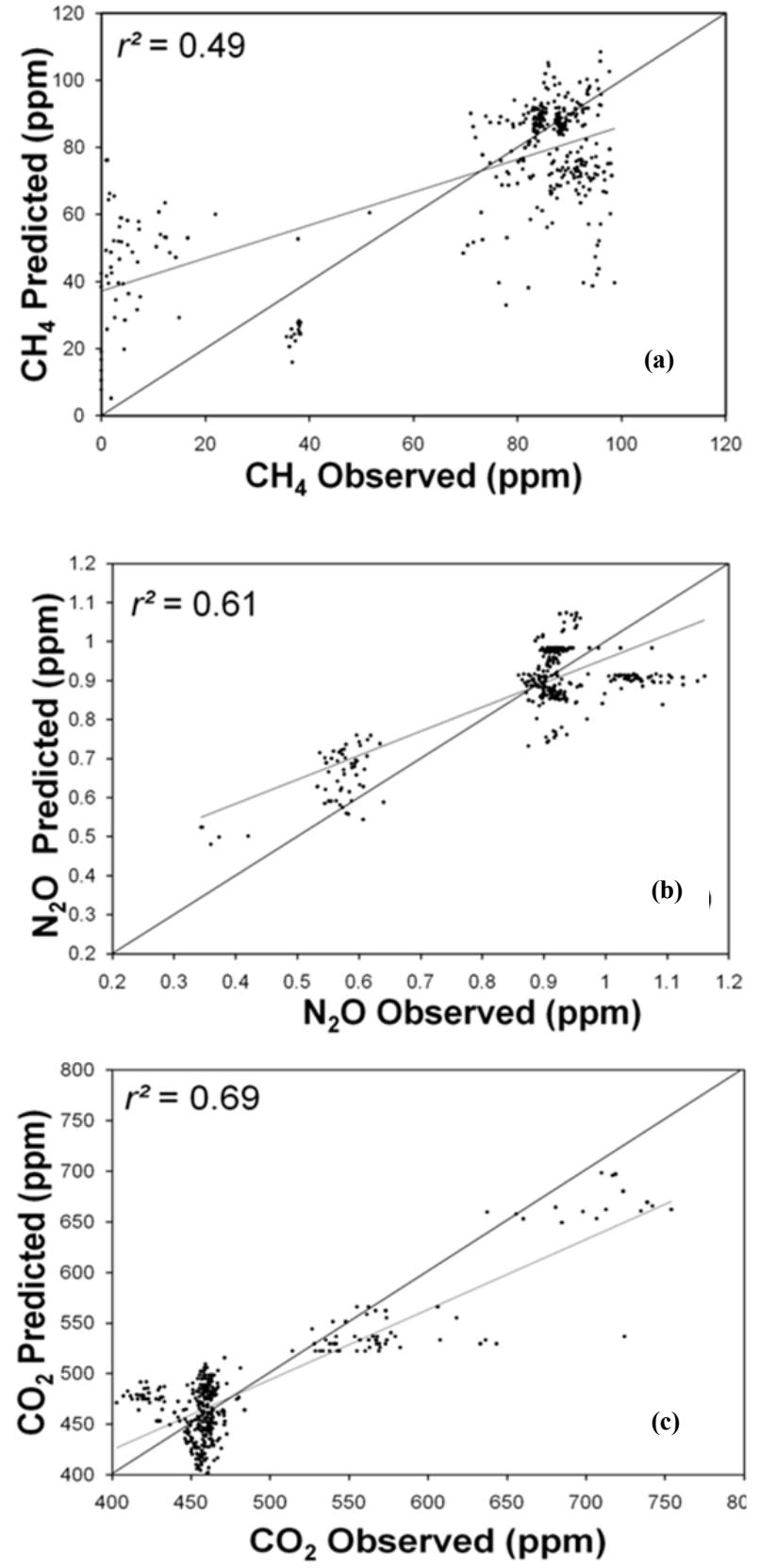

Figure 6. Comparison of statistical models applied to the 5-day February ensemble for: (a) $\mathrm{CH}_{4}$, (b) $\mathrm{N}_{2} \mathrm{O}$, and (c) $\mathrm{CO}_{2}$.

\section{DISCUSSION AND FINAL REMARKS}

This study presented a lower-cost method for estimating energy fluxes and GHG emission. The system is based on the relationship between the meteorological physical variables that characterize the state of the waste lagoon and overall GHG emissions. A series of meteorological and GHG measurements were completed to quantify their relationships. Relative humidity and temperature, with the latter measured above and below the surface of the lagoon, served to characterize the energy fluxes at the lagoon interface. Measurements of several GHGs were available for a 5-day period during 5, 7, 8, 9 and 12 February. A corresponding 5-day hourly ensemble of atmospheric and 
lagoon variables were used to generate statistical models to predict the observed behavior. The models were able to explain $49 \%$ to $69 \%$ of the observed variance for $\mathrm{CO}_{2}, \mathrm{CH}_{4}$ and $\mathrm{N}_{2} \mathrm{O}$ when the predictors were temperature at $0.5 \mathrm{~m}$, temperature at the $\mathrm{HOBO}$ station, lagoon temperature, wind speed at $0.5 \mathrm{~m}$, latent heat flux from the lagoon surface and solar radiation. Strong relationships were found between $\mathrm{CO}_{2}$ and the air temperature and wind speed, with both measured at $0.5 \mathrm{~m}$ above the lagoon surface. Calculated $r^{2}$ between the observed and modeled data for $\mathrm{CO}_{2}$ was 0.69 . For $\mathrm{N}_{2} \mathrm{O}$ and $\mathrm{CH}_{4}$ models, these values were 0.62 and 0.49 , respectively. Lagoon surface temperature and solar radiation were better predictors for $\mathrm{N}_{2} \mathrm{O}$ while air temperature and latent heat flux from the lagoon played the same role for $\mathrm{CH}_{4}$. The smaller correlations obtained for the GHGs and rest of the lagoon physical parameters (not shown) seemed to point to different pathways in which the chemistry was influenced by the physical conditions of the lagoon. This was particularly true for $\mathrm{CH}_{4}$. We suggest that longer-term GHG emissions and meteorological data collection from waste lagoons systems are essential and urgent for a better understanding of the relationship between these two factors. Such advances may also provide the context for the development of regular, short-term meteorological forecasting of days suitable for waste and waste lagoon management and, thus, BMPs and potential reductions in GHG emissions.

\section{ACKNOWLEDEMENTS}

The authors thank two reviewers and the editor for their valuable comments and suggestions which helped to improve this manuscript. This work is funded by the USDA grant \#58-6445-6-068. It also benefitted from a NSF REU grant \#1004655. The authors thank Joe St. Claire, and Marty Haley for construction and maintenance of field equipment.

\section{REFERENCES}

Andreas, E. L., and B. A. Cash. 1996. A new formulation for the Bowen ratio over saturated surfaces. J. Appl. Meteorol. 35(8): 1279-1289.

Arya, S. P. 2001. Introduction to Micrometeorology. Geophysics Series 79. San Diego, Calif.: Academic Press.

Assouline, S., B. A. Cash, J. Tanny, S. Cohen, E. Bou-Zeid, M. B. Parlange, and G. G. Katul. 2008. Evaporation from three water bodies of different sizes and climates: Measurements and scaling analysis. Adv. Water Res.31(1): 160-172.

Bowen, I. S. 1926. The ratio of heat losses by conduction and evaporation from any water surface. Phy. Rev. 27(6): 779-787.

Brutsaert,W. 2005. Hydrology: An Introduction. New York, N.Y.: Cambridge University Press.

Condie, S. A., and I. T. Webster. 1997. The influence of wind stress, temperature, and humidity gradients on evaporation from reservoirs. Water Res. Res. 33(12): 2813-2822.

Crawford, T. M., and C. E. Duchon. 1999. An improved parameterization for estimating effective atmospheric emissivity for use in calculating daytime downwelling longwave radiation. J. App. Meteorol. 38(4): 474-480.

Cohen, S., A. Ianetz, and G. Stanhill. 2002. Evaporative climate changes at Bet Dagan, Israel, 1964-1998. Agric. For. Meteorol. 111(2): 83-91.
De Jong, R., C. F. Shaykewich, and A. Reimer. 1980. The net radiation flux and its prediction at Pinawa, Manitoba. Agric. Meteorol. 22(3-4): 217-225.

DeSutter, T. M., and J. M. Ham. 2005. Lagoon-biogas emissions and carbon balance estimates of a swine production facility. $J$. Environ. Qual. 34(1): 198-206.

Doorenbos, J., and W. O. Pruitt. 1977. Crop Water Requirements. Irrigation and Drainage Paper, No. 24, Rome, Italy: FAO.

Elsawwaf, E., P. Willems, A. Pagano, and J. Berlamont. 2010. Evaporation estimates from Nasser Lake, Egypt, based on three floating station data and Bowen ratio energy budget. Theor. Appl. Climatol.10(3-4): 439-465.

Garratt, C., R. Outerbridge, and K. Thompson. 1993. Internal variability in Mediterranean heat and buoyancy fluxes. J. Clim. 6(5): 900-910.

Ham, J. M. 1999. Estimating evaporation and seepage losses from lagoons used to contain animal waste. Trans. ASAE 42(5): 13031312.

Harper, L. A., R. R. Sharpe, T. B. Parkin, A. De Visscher, O. van Cleemput, and F.M. Byers. 2004. Nitrogen cycling through swine production systems: Ammonia, dinitrogen, and nitrous oxide emissions. J. Env. Quality 33(4): 1189-1201.

Irmak, A., and S. Irmak. 2008. Reference and Crop evapotranspiration in South Central Nebraska. II: Measurement and estimation of actual evapotranspiration for corn. J. Irr. and Drain. Engr. 134(6): 700-715.

Jacobs, A. F. G., B. G. Heusinkveld, A. Kraai, and K. P. Paaijmans. 2008. Diurnal temperature fluctuations in an artificial small shallow water body. Int. J. Biometeorol. 52(4): 271-280.

Komzsik, L. 2007. Approximation Techniques for Engineers. Boca Raton, Fla.: CRC, Taylor and Francis.

Krishnan, A. and R. S. Kushwaha. 1971. A crititcal study of evaporation by Penman's method during the growing season of vegetation in the arid zones of India. Theor. Appl. Climatol. 19(3): 267-276.

Linacre, E. T. 1968. Estimating the net-radiation flux. Agric. Meteorol. 5(1): 49-63.

Loughrin, J. H., A. I. Quintanar, N. Lovanh, and R. Mahmood. 2011. Heat flux measurements and modeling of malodorous compounds above an anaerobic swine lagoon. Water Air Soil Poll. 217(1-4): 463-471.

Loughrin, J. H, A. I. Quintanar, K. L. Cook, N. C.Lovanh, R. Mahmood, and E. Becerra-Acosta 2012. Seasonal variation in heat fluxes, predicted emissions of malodorants, and wastewater quality of an anaerobic swine waste lagoon. Water Air Soil Poll. DOI:10.1007/s11270-012-1134-4.

Loughrin, J. H., A. A. Szogi, and M. B. Vanotti. 2006. Reduction of malodorous compounds from a treated swine anaerobic lagoon. J. Env. Quality 35(1): 194-199.

Lovanh, N., J. H. Loughrin, K. Cook, M. Rothrock, and K. Sistani. 2009. The effect of stratification and seasonal variability on the profile of an anaerobic swine waste treatment lagoon. Bioresour. Tech. 100(15): 3706-3712.

Mahmood, R., and K. G. Hubbard. 2002. Anthropogenic land use change in the North American Tall Grass-Short grass transition and modification of near surface hydrologic cycle. Clim. Res. 21(1): 83-90.

Mahmood, R., and K. G. Hubbard. 2003. Simulating sensitivity of soil moisture and evapotranspiration under heterogeneous soils and land uses. J. Hydrol. 280(1-4): 72-90.

Mahmood, R., and K. G. Hubbard. 2005. Assessing bias in evapotranspiration and soil moisture estimates due to the use of modeled solar radiation and dew point temperature data. Agric. For. Meteorol. 130(1-2): 71-84. 
Mesinger, F., G. DiMego, E. Kalnay, K. Mitchell, P. C. Shafran, W. Ebisuzaki, D. Jovic, J. Woollen, E. Rogers, E. H. Berbery, M. B. Ek, Y. Fan, R. Grumbine, W. Higgins, H. Li, Y. Lin, G. Manikin, D. Parrish, and W. Shi. 2006. North American Regional Reanalysis. Bull. Amer. Meteor. Soc. 87(3): 343-360.

Mangino, J., D. Bartram, and A. Brazy. 2002. Development of a methane conversion factor to estimate emissions from animal waste lagoons. Available at http://epa.gov/ttn/chief/conference/ei11/ammonia/mangino.pdf

Novak, M. D., W. Chen, and M. A. Hares. 2000. Simulating the radiation distribution within a barley-straw mulch. Agric. For. Meteorol. 102(2): 173-186.

Ohmura, A. 1982. Objective criteria for rejecting data for Bowen ratio calculations. J. Appl. Meteorol. 21(4): 595-598.

Oke, T. R. 1987. Boundary Layer Climates. New York, N.Y.: Routledge.

Penman, H. L. 1948. Natural evaporation from open water, bare soil and grass. Proc. Royal Soc. London. Series A, Math. Phys. Sci. 193(1032): 120-146.

Perez, P. J., F. Castellvi, M. Ibanez, and I. J. Rosell. 1999. Assessment of reliability of Bowen ratio method for partitioning fluxes. Agric. For. Meteorol. 97(3): 141-150.

Philip, R. J. 1987. A physical bound on the Bowen ratio. J. Appl. Meteorol. 26(8): 1043-1045.

Priestley, C. H. B., and R. J. Taylor. 1972. On the assessment of surface heat flux and evaporation using large-scale parameters. Mon. Wea. Rev. 100(2): 81-92.

Quintanar, A. I., R. Mahmood, J. Loughrin, N. C. Lovanh, and M. V. Motley. 2009. A system for estimating Bowen Ratio and evaporation from waste lagoons. Appl. Eng. Agric. 25(6): 923932.

Rodríguez-Rodríguez., and M. Moreno-Ostos, M. 2006. Heat budget, energy storage and hydrological regime in a coastal lagoon. Limnologica 36(4): 217-227.

Sharpe, R. R., L. A. Harper, and F. M. Byers. 2002. Methane emissions from swine lagoons in southeastern US. Agric. Ecosys. Env. 90(1): 17-24.

Shnitnikov, A. V. 1974. Current methods for the study of evaporation from water surfaces and evapotranspiration. Hydrol. Sci. Bull. 19(1): 85-97.

Smith, N. P. 1985. The suitability of routine weather data for estimating local estuarine heat energy fluxes. Estuaries 8(3): 270-278.

Spence, C., R. W. Rouse, D. Worth, and C. Oswald. 2003. Energy budget processes of a small northern lake. J. Hydrometeorol. 4(4): 694-701.

Stannard, D. I. 1997. A theoretically based determination of Bowen ratio fetch requirements. Bound.-Layer Meteorol. 83(3): 375406.

Steinfeld, H., P. Gerber, T. Wassenaar, V. Castel, M. Rosales, and C. de Haan. 2006. Livestock's long shadow: Environmental issues and options. Rome: FAO.

Tanny, J., S. Cohen, S. Assouline, F. Lange, A. Grava, D. Berger, B. Teltch, and M. B. Parlange. 2008. Evaporation from a small water reservoir: Direct measurements and estimates. J. Hydrol. 351(1-2): 218-229.

Wetzel, R.G., and G. E. Likens. 1991. Limnological Analyses. New York, N.Y.: Springer-Verlag.

Wang, K., and S. Liang. 2009. Estimation of daytime net radiation from shortwave radiation measurements and meteorological Observations. J. Appl. Meteorol. Climatol. 48(3): 634-643.

Wohlfahrt, G., A. Haslwanter, L. Hörtnagl, R. L. Jasoni, L. F. Fenstermaker, J. A. Aronne III, and A. Hammerle. 2009. On the consequences of the energy imbalance for calculating surface conductance to water vapour. Agric. For. Meteorol. 149(9): 1556-1559.

\section{APPENDIX}

To calculate the $L S$, the time change of lagoon temperatures was integrated from the surface to the total depth of the lagoon (Arya, 2001; Brutsaert, 2005):

$$
L S(t)=\int \frac{\partial}{\partial t}\left(\rho C_{w} T\right) d z
$$

where $\rho\left(\mathrm{kg} \mathrm{m}^{-3}\right)$ is density of water, $C_{w}\left(\mathrm{~J} \mathrm{~K}^{-1} \mathrm{~kg}^{-1}\right)$ represents the specific heat of water, and $T$ corresponds to the vertical profile of water temperature $(\mathrm{K})$. To compute the above integral, a trapezoidal rule is implemented given several temperature measurements along the vertical extent of the water column (Komzsik, 2007). With the assumptions that the depth of the lagoon area (Wetzel and Likens, 1991), $\rho$, and $C_{w}$ are constants, the integral (eq. 2) can be estimated as:

$$
L S=\frac{\rho C_{w}}{2 \Delta t} \sum_{i=1}^{N} \delta_{i}\left(\Delta T_{i-1}+\Delta T_{i}\right)
$$

where $\Delta T_{i}$ represents the temperature time change at a specific temperature sensor (first, second, etc.) in the water column at a time step of $\Delta t . \Delta T_{0}$ is the temperature change with time at the lagoon surface. $N$ is the number of thermal sensors at or below the surface. The term $\delta_{i}$ stands for the depth of the layer at which the temperature is to be measured, with the temperature at the center-point of the layers represented by is $1 / 2\left(T_{i-1}+T_{i}\right)$.

The outgoing long-wave radiation $\left(R_{L U}\right)$ is approximated with the following equation:

$$
R_{L U}=\varepsilon_{S} \sigma T_{S}^{4}
$$

where $\sigma$ is the Stefan-Boltzmann constant $\left(5.67 \times 10^{-8} \mathrm{~W} \mathrm{~m}^{-2}\right.$ $\mathrm{K}^{-4}$ ) and $T_{S}$ is the absolute temperature of the lagoon surface. The incoming long-wave radiation $\left(R_{L D}\right)$ term is written as:

$$
R_{L D}=\varepsilon_{A C} \sigma T_{A}^{4}\left(z_{1}\right)
$$

where $\varepsilon_{A C}$ is the emissivity of the atmosphere and $T_{A}$ is atmospheric temperature at $z_{l}$, which was set to $0.5 \mathrm{~m}$ for this study. Assuming clear, sunny conditions, the $\varepsilon_{A C}$ term is expressed as:

$$
\varepsilon_{A C}=A\left(\frac{e\left(z_{2}\right)}{T_{A}}\right)^{B}
$$

where $e\left(z_{2}\right)$ is the approximated vapor pressure at height $z_{2}$ ( $1.5 \mathrm{~m}), A=1.16$, and $B=1 / 7$. The values for $A$ fluctuate over the course of a year, thus a method that takes into account seasonal variations was implemented from Crawford and Duchon (1999). 